\title{
Energy-economic-environmental analysis of solar drying system: a review
}

\author{
Wan Nurlaila Yusra Mat Desa ${ }^{1}$, Ahmad Fudholi², Zahira Yaakob ${ }^{3}$ \\ ${ }_{1,2}$ Solar Energy Research Institute, Universiti Kebangsaan Malaysia, Malaysia \\ ${ }^{3}$ Research Center for Sustainable Process Technology (CESPRO), Faculty of Engineering and Built Environment, \\ Universiti Kebangsaan Malaysia, Malaysia
}

\begin{tabular}{|c|c|}
\hline Article Info & ABSTRACT \\
\hline Article history: & Solar drying is an emerging technology to preserve wide range of products \\
\hline Received Jan 30, 2019 & $\begin{array}{l}\text { from agriculture to animal-based products. The application of solar dryers, } \\
\text { however must be evaluated to determine its benefit and effectiveness. In the }\end{array}$ \\
\hline Revised Jul 8, 2019 & evaluation of solar dryer performance, three criteria which are most \\
\hline Accepted Jan 30, 2020 & $\begin{array}{l}\text { important to look at are thermal performance, economic cost and } \\
\text { environmental implications. Therefore, this paper attempts to review the }\end{array}$ \\
\hline Keywords: & $\begin{array}{l}\text { thermoeconomic analysis and environmental evaluation on various solar } \\
\text { drying system. Performance equations in energy-economic-environment }\end{array}$ \\
\hline Drying materials & analyses for solar drying syistems evaluation are presented. The $\mathrm{CO} 2$ \\
\hline Renewable energy & $\begin{array}{l}\text { syistem are also presented. } \\
\text { sion sor arying }\end{array}$ \\
\hline
\end{tabular}

This is an open access article under the CC BY-SA license.

Solar dryer
Solar energy

(c) ()

\section{Corresponding Author:}

Ahmad Fudholi,

Solar Energy Research Institute,

Universiti Kebangsaan Malaysia, 43600 Bangi Selangor, Malaysia.

Email: a.fudholi@ukm.edu.my

\section{INTRODUCTION}

In the recent years of energy research, renewable sources are gaining much attention as the world is shifting from fossil fuel to alternative energy. One of the reasons that drives this shift is due to the increasing demand for energy in the future, that initiate the exploration for a more sustainable energy sources to last to the end of human lifetime. The alarming scene of environmental degradation and pollution is also another main reason that pushes for cleaner, and more responsible energy generation. Solar energy is the most accessible, readily available, and highly potential as renewable source of energy generation. The amount of solar radiation intensity that reaches the outer atmosphere is $1,360 \mathrm{~W} / \mathrm{m}^{2}$, and after accounting for natural losses, the global radiation that reaches the ground is still high at the range of $800-1000 \mathrm{~W} / \mathrm{m}^{2}$, on a clear sky sunny day in summer [1]. Due to its energetic potentials, solar energy is converted into useful applications in the form of thermal and electrical energy. Solar energy is widely used in solar thermal technology such as in solar collector systems [2-4], in photovoltaic/thermal systems [5-16] and in solar drying systems [17-21].

The role of solar thermal is theorized to be able to lower the burden on scarce renewable resources and also to supply renewable energy in conditions where no alternatives are available [22]. While the application for solar thermal systems is widely known in domestic sector, it also provides huge potential for industries to benefit from. Kylili et al. conducted a life-cycle assessment (LCA) on industrial solar thermal system (ISTS) in the Europe, and found significant energy and carbon savings from its application, which ranges from $35-75 \mathrm{GJ}$ and $2-5$ tonnes of $\mathrm{CO}_{2}$ per $\mathrm{kWth}$ depending on the geographical location, respectively [23]. 


\section{SOLAR DRYING PRINCIPLE AND MECHANISMS}

Drying is a method of food preservation that has been practiced for centuries. It is a common practice to extend the shelf life of different kind of food products, from fruits, herbs, and animal and marine based products. In drying, excess moisture from food products are removed due to thermal action. The resulting end products with moisture reduction inhibits microbial growth which enables them to be stored for future use. During moisture removal, simultaneous process of mass and heat transfer take place within the sample, outer surface and heating air. However, despite its reliability to preserve food products, drying process is highly energy intensive which consumes about $50 \%$ energy of the food processing industry [24]. The energy requirement for drying process is high because of the latent heat of vaporization involved to vaporize excess moisture from the products.

Solar drying provides an alternative to the conventional drying process. In contrary to sun drying, where food products are being exposed to dry directly under the sun, solar drying utilizes heat entrapment mechanism to enhance the moisture removal process. The application of solar dryer converts solar energy using solar collector unit into useful thermal energy. Thus, solar dryer systems are capable to increase the operating temperature to $50-60{ }^{\circ} \mathrm{C}$ which resulted in perfect drying and product quality [25]. Due to higher drying temperature, solar dryer minimizes the area needed to expose the products to hot air. Solar dryer is also less dependent on sunshine availability, as it can utilized thermal energy storage systems and auxiliary heating unit for heat supply. Construction of solar dryers includes drying chamber, which isolates the products from ambient surroundings. Thus, final products from solar driers are less susceptible to contamination from dust, insects, and microbial growth.

Primarily, solar dryer can be categorized into four groups; direct solar dryer, indirect solar dryer, mixed-mode solar dryer, and hybrid solar dryer [26]. The working principle of each dryer is different in terms of solar energy conversion to thermal energy. In direct solar dryer, heat is generated by direct absortion of solar irradiation on the product as sun rays penetrate through transparent chamber, while indirect dryer utilizes solar radiation on collector unit to heat up air, which indirectly dry the materials [27]. Mixed-mode dryer utilizes both direct mode in drying chamber, and indirect mode in its collector unit, where as hybrid dryer on the other hand refers to the usage of supplementary source of energy i.e. biomass, diesel engine, photovoltaic integration to supply heat.

\section{EXPERIMENTAL EVALUATION}

Due to wide availability of solar drying systems in practice, the development of solar dryer technologies needs to be based on empirical knowledge of its energy profile and the anticipated performance over its expected life-time. The information acquired from empirical evaluations is relevant to determine and improve the plant and operation costs, energy conservations, fuel versatility and pollutants [28]. In addition, selection of the right dryers must take into consideration the user's need and the end use of dried products, thus require the evaluation the following domains: social, technical and economic functions [29].

\subsection{Energy Analysis}

Solar dryers take into application of energy conversion from solar to useful thermal energy for drying process. For this purpose, numerous methods and processes were developed and their effectiveness can be evaluated on many merits, such as energy efficiency, time to dry and product quality. In solar drying, thermal performance is a reliable indicator to study the system merits and can be quantified using energy analysis. Energetic performance is based on the first law of thermodynamics, which takes in to account the quantity of energy and the energy change in respect to the change in surroundings [30]. However, the drawbacks of energy analysis is that it only considers energies at inlet and outlet of the system, and sometimes is redeemed as insufficient for system optimization as it neglects the irreversibility and thermodynamic losses [31-33].

In general, energetic analysis on solar dryers can be done on two main components; the drying systems and the drying materials. Drying systems of solar dryers includes the solar absorber unit, drying chamber, and movement of heated drying air throughout the system. In short, energy analysis of solar dryer components is commonly done by applying heat transfer and energy balance based on the principle of energy conservation of the first law of thermodynamics. Determination of thermal performance of solar dryers are important to achieve maximum moisture removal while using minimum amount of energy [28].

In literature, there are several indicators that are commonly used to evaluate the thermal capacity of solar dryer components, especially for solar collector unit. The amount of useful heat that can be harness from solar collector can be calculated using heat removal factor, $F_{R}$ and the incident solar radiation, $I_{t} . Q_{u}$ value is depended on the material of construction used for collector, as well as the surface area, as suggested by (1) [34].

Int J Pow Elec \& Dri Syst, Vol. 11, No. 2, June 2020 : 1011 - 1018 


$$
Q_{u}=F_{R} A_{c}\left[I_{t}(\tau \alpha)-U_{L}\left(T_{i}-T_{a}\right)\right]
$$

The energy used for moisture evaporation can be calculated as [35]

$$
E_{\text {vap }}=M_{\text {water }} H_{f g}
$$

Thermal efficiency of solar collector is the ratio of heat gain by air passing through the collector to the energy gained due to solar irradiation, given by [36-38].

$$
\eta_{c}=\frac{m c\left(T_{o u t}-T_{\text {in }}\right)}{A_{c} I} \times 100 \%
$$

Another indicator commonly used in energetic analysis is the thermal efficiency of solar dryers, $\eta_{d}$. Essentially, $\eta_{d}$ is the ratio of energy required to evaporate product's moisture to the energy consumed for the drying process. In short, thermal efficiency of the drying system is the ratio of the energy used for moisture evaporation to the energy input to the drying system.

$$
\eta_{d}=\frac{E_{\text {evap }}}{E_{\text {input }}}
$$

In passive convection dryers, dryer efficiency calculation is based on the air movement due to natural buoyancy, whereas active dryers takes into account the energy input through electrical fans or blowers, given by respectively [39], [40]. Depending on the type of solar drying system, the energy consumed for drying process would need to account for all source of energy generated in the system. In hybrid system, usually photovoltaic-thermal (PVT) hybrid dryers, electrical efficiency of solar collector is quantified as the system takes electricity into energy generation.

$$
\begin{aligned}
\eta_{d, P} & =\frac{m L_{v}}{A_{c} I t_{d}} \\
\eta_{d, A} & =\frac{m L_{v}}{A_{c} I+P_{f}}
\end{aligned}
$$

The relationship between energy input to solar dryer and amount of water evaporated can also be used to define the performance of the dryer and to compare performance of the dryers. is Specific moisture extraction rate (SMER) in $\mathrm{kg} \mathrm{kWh}^{-1}$ relates how much moisture can be removed per unit of energy, whereas specific energy consumption (SEC) is the reciprocal of SMER with units of $\mathrm{kWh} \mathrm{kg}^{-1}$ [41]

$$
\begin{aligned}
& S M E R=\frac{\text { Amount of moisture evaporated }}{\text { Energy input to the dryer }} \\
& S E C=\frac{\text { Energy input to the dryer }}{\text { Amount of moisture evaporated }}
\end{aligned}
$$

Pickup efficiency, or moisture removing efficiency of drying air is the efficiency measure on moisture extraction using hot air, and it can be calculated using

$$
\eta=\frac{h_{o}-h_{i}}{h_{a s}-h_{i}}=\frac{W}{v \rho\left(h_{a s}-h_{i}\right)}
$$

In hybrid systems where energy source comes from other than solar energy, solar fraction is determined to quantify the ratio of energy extraction of heat from solar collector to the overall energy available for the drying process [35]. Solar fraction can be expressed by

$$
S F=\frac{Q_{s}}{Q_{t}}=\frac{\text { Heat gain at collector }}{\text { Total heat supplied to dryer }}
$$

From the drying material components, effectiveness of drying can be associated with moisture reduction within the samples. The mass of water removed (W) from a wet product can be calculated by [28]

$$
W=\frac{m_{o}\left(M_{i}-M_{f}\right)}{100-M_{i}}
$$


Moisture ratio, which is a dimensionless form of moisture content explains the ratio of remaining moisture to be removed at time $t$ over initial total moisture present. In the study of drying, MR is an important tool to understand the kinetics and drying profile as they vary from one material to another. In fact, $\mathrm{MR}$ is found to be mostly adequate to describe the drying behavior of some fruits and vegetables as it translates to drying constant, $k\left(\mathrm{~s}^{-1}\right)$. This is an important parameter widely used in thin-layer modelling, to obtain drying curve as a function of time [42].

$$
M R=\frac{\left(M-M_{e}\right)}{\left(M_{O}-M_{e}\right)}
$$

\subsection{Economic Analysis}

While energy analysis is a common approach used to minimize thermodynamic efficiencies within dryer system, thermoeconomic is a different take to estimate the cost-optimal structure and the optimal values of thermodynamic efficiencies in each component [43]. Thermoeconomic is viewed as a promising diagnostic tool, even for complex system [32]. Through economic analysis, solar dryer application has been proved to have undeniable improvement on carbon footprint reduction associated with the energy-intensive drying process. In a review article by Mathew et al., solar dryers are highly effective device with low investment to produce good quality of dried products. The unit cost of useful energy for solar dryers were found to vary from 0.0034 to 0.015 USD per MJ of energy for different types of drying products [44].

El-Hage et al. conducted an economic study to evaluate monetary savings due to application of industrial solar dryers under Lebanese climate. The energy cost saving is determined on monthly basis, where it is dependent on the percentage of time where solar dryer is used, Pr, the dryer energy consumption for operation $E_{\text {month }}$, and the cost of electricity for one unit of $\mathrm{kWh}, P_{k W h}$. Depending on the $\operatorname{Pr}$ value which ranges from 0.1 to 1 , the energy cost reduction records savings between $\$ 130$ to $\$ 4160$ per month for drying of $120 \mathrm{~kg}$ of various vegetable samples.

$$
S M=P_{r} \times E_{\text {month }} \times P_{k W h}
$$

From the determined SM and capital cost of the solar dryer, simple payback period (PP) for the dryer system was determined as follows

$$
P P=\frac{C_{\text {dryer }}}{S M}
$$

A more detailed economic analysis was performed by ELkhadraoui et al. who evaluated the economics of chapel-shaped greenhouse for red pepper and grape drying in Tunisia [45]. The payback period for the dryer system was determined to be short at 1.6 years. The calculation used takes into account the capital cost of the dryer $C_{c c}$, inflation rate $\mathrm{i}$, interest rate on long term investment $\mathrm{d}$, and the saving during first year of the dryer $S_{1}$. This method of calculation is also used by [40], [46].

$$
P P=\frac{\ln \left[1-\frac{C_{c c}}{S_{1}}(d-i)\right]}{\ln \left(\frac{1+i}{1+d}\right)}
$$

Another approach for economic analysis is the incorporation of cost-benefit analysis to compare cost and benefits of solar drying to other means by taking into consideration the size, materials for construction, efficiency, operation, sophistication and sustainability of the driers which vary from countries to country. Past study on economic analysis on solar drying systems as show in Table 1.

\subsection{Environmental Analysis}

In practice, percentage of reductions on fuel consumption depends on the type and solar dryer system. The range of savings recorded can vary from 20-40 percent in hybrid systems, to total fuel elimination in natural ventilation greenhouse solar dryer [50]. Past study on environmental analysis on solar drying systems as shown in Table $2 . \mathrm{CO}_{2}$ mitigation is a tool to measure climate change potential with the opportunity to reduce greenhouse effect emission by capping total annual emissions and letting the market assign a monetary value to any shortfall through trading [51]. In carbon credit model, monetary incentives allow transactions among businesses and individuals to get involve in carbon footprint reduction and at the same time funds reduction schemes globally. Carbon credit is the component of energy analysis. A carbon credit is a generic term for any tradable certificate or permit representing the right to emit one tone of carbon or carbon dioxide equivalent. Carbon trading is also an application of an emission trading approach [22].

Int J Pow Elec \& Dri Syst, Vol. 11, No. 2, June 2020 : 1011 - 1018 
Table 1. Past study on economic analysis on solar drying systems

\begin{tabular}{|c|c|c|c|c|c|}
\hline Ref. & Year & $\begin{array}{l}\text { Solar Dryer } \\
\text { Type }\end{array}$ & $\begin{array}{l}\text { Drying } \\
\text { materials }\end{array}$ & Indicator & Findings \\
\hline [45] & 2015 & $\begin{array}{l}\text { Mixed mode } \\
\text { greenhouse SD }\end{array}$ & $\begin{array}{l}\text { Red pepper } \\
\text { and grape }\end{array}$ & $\begin{array}{l}\text { Annualized cost of dryer } \\
\text { Annualized capital cost (Cac) } \\
\text { Annual electricity cost for } \\
\text { fans } \\
\text { Annual savings }(\mathrm{Sj}) \text { for } \\
\text { drying the typical product in } \\
\text { the jth year } \\
\text { Payback period }\end{array}$ & $\begin{array}{l}\text { Dryer capital cost is } 660 \text { USD, and } \\
\text { Payback period is } 1.6 \text { years compared to } \\
20 \text { years of lifetime. }\end{array}$ \\
\hline [40] & 2016 & $\begin{array}{l}\text { Modified } \\
\text { greenhouse } \\
\text { dryer }\end{array}$ & Potato chips & Payback period & Payback period is 1.11 years. \\
\hline [47] & 2018 & $\begin{array}{l}\text { Indirect cabinet } \\
\text { SD }\end{array}$ & $\begin{array}{l}\text { Carrot, } \\
\text { Corn, } \\
\text { Mushrooms, } \\
\text { Potatoes, } \\
\text { Apples, } \\
\text { Banana, } \\
\text { Cherries, } \\
\text { Peaches }\end{array}$ & $\begin{array}{l}\text { Amount of saved money } \\
\text { Payback period }(\mathrm{PP})\end{array}$ & $\begin{array}{l}\text { The capital cost of dryer is } 8000 \text { USD, and } \\
\text { savings recorded range from } 1400 \text { USD to } \\
12500 \text { USD depending on mass and type of } \\
\text { drying sample and percentage of dryer } \\
\text { utilization. From this, the payback period } \\
\text { range from } 0.9 \text { to } 62 \text { months. }\end{array}$ \\
\hline [48] & 2005 & Unknown SD & $\begin{array}{l}\text { Various } \\
\text { agri-produce }\end{array}$ & $\begin{array}{l}\text { Capital cost of dryer } \\
\text { Unit cost of drying } \\
\text { Unit cost of useful energy } \\
\text { Valuation of benefits }\end{array}$ & \\
\hline [49] & 2014 & $\begin{array}{l}\text { Low cost SD - } \\
\text { Direct and } \\
\text { indirect passive } \\
\text { dryers }\end{array}$ & Fish & $\begin{array}{l}\text { Fixed cost - constructiona } \\
\text { and maintenance cost } \\
\text { Qualitative performance } \\
\text { evaluation }\end{array}$ & \\
\hline [23] & 2018 & & & Carbon savings & $\begin{array}{l}\text { Life-cycle assesment on environmental } \\
\text { performance of industrial solar thermal } \\
\text { system (ISTS). Large- scale ISTS } \\
\text { applications were found to achieve energy } \\
\text { and carbon savings ranging from } 35-75 \\
\text { GJ and } 2-5 \text { tonnes of CO } 2 \text { per kWth, } \\
\text { depending on the geographical location. }\end{array}$ \\
\hline [44] & 2018 & Various & & & $\begin{array}{l}\text { The economic analysis of different driers } \\
\text { has been discussed in this article. }\end{array}$ \\
\hline
\end{tabular}

Table 2. Past study on environmental analysis on solar drying systems

\begin{tabular}{|c|c|c|c|c|c|}
\hline Ref. & Year & $\begin{array}{l}\text { Solar Dryer } \\
\text { Type }\end{array}$ & $\begin{array}{l}\text { Drying } \\
\text { materials }\end{array}$ & Indicator & Findings \\
\hline [51] & 2011 & $\begin{array}{l}\text { Hybrid PVT } \\
\text { Greenhouse }\end{array}$ & Mint leaves & $\begin{array}{l}\mathrm{CO} 2 \text { mitigation over the } \\
\text { lifetime } \\
\text { Net mitigation over lifetime } \\
\text { Earned carbon credit }\end{array}$ & $\begin{array}{l}\text { CO2 mitigation is } 140.97 \text { tons and earned } \\
\text { credit of } 704.85-2819.4 \text { USD. }\end{array}$ \\
\hline [40] & 2016 & $\begin{array}{l}\text { Modified } \\
\text { greenhouse } \\
\text { dryer }\end{array}$ & $\begin{array}{l}\text { Potato } \\
\text { chips }\end{array}$ & $\begin{array}{l}\text { Embodied energy } \\
\text { Energy payback time } \\
\mathrm{CO} 2 \text { emission } \\
\mathrm{CO} 2 \text { mitigation per } \mathrm{kWh} \\
\text { Earned carbon credit }\end{array}$ & $\begin{array}{l}\text { Embodied energy is } 480.277 \text { and } 628.73 \\
\mathrm{kWh} \text { for passive and active mode, } \\
\text { respectively. Annual CO2 emission is } 13.45 \\
\text { and } 17.6 \mathrm{~kg} \text { for passive and active mode, } \\
\text { respectively. The average EPBT, carbon } \\
\text { mitigation, and earned carbon credit for } \\
\text { passive dryer is } 1.04 \text { year, } 32.36 \text { tons, and } \\
375 \text { USD while active dryer is } 1.3 \text { year, } 33.9 \\
\text { tons, and } 393 \text { USD, respectively. }\end{array}$ \\
\hline [46] & 2014 & $\begin{array}{l}\text { modified } \\
\text { greenhouse } \\
\text { dryer under } \\
\text { active mode }\end{array}$ & Tomato & $\begin{array}{l}\mathrm{EE} \\
\text { EPBT } \\
\mathrm{CO}_{2} \text { emission } \\
\text { Carbon mitigation } \\
\text { Earned credit }\end{array}$ & $\begin{array}{l}\text { Embodied energy is } 628.7287 \mathrm{kWh} \text {. Low } \\
\text { EPBT of } 1.14 \text { years. Annual CO2 emission } \\
\text { is } 17.6 \mathrm{~kg} \text {, with net } \mathrm{CO} 2 \text { mitigation of } 38.06 \\
\text { tons. Earned carbon credit varies from } 176 \text { - } \\
706 \text { USD. }\end{array}$ \\
\hline$[52]$ & 2017 & Indirect SD & Fenugreek & $\begin{array}{l}\mathrm{EE} \\
\mathrm{EPBT} \\
\mathrm{CO}_{2} \text { emission } \\
\mathrm{CO}_{2} \text { mitigation } \\
\text { Carbon credit }\end{array}$ & $\begin{array}{l}\text { Embodied energy of the dryer is } 1081.8 \\
\mathrm{kWh} \text {. EPBT of } 4.36 \text { years, annual CO2 } \\
\text { emission of } 85.46 \mathrm{~kg} \text {, and CO } 2 \text { mitigation of } \\
391.52 \mathrm{~kg} \text {. The earned carbon credit ranges } \\
\text { from } 660 \text { - } 2061 \text { USD. }\end{array}$ \\
\hline [47] & 2018 & $\begin{array}{l}\text { Indirect } \\
\text { cabinet SD }\end{array}$ & $\begin{array}{l}\text { Vege and } \\
\text { fruits }\end{array}$ & $\begin{array}{l}\text { Amount of } \mathrm{CO}_{2} \text { produced } \\
\text { Amount of } \mathrm{CO}_{2} \text { reduction }\end{array}$ & $\begin{array}{l}\text { Range of } \mathrm{CO} 2 \text { reduction from } 20500-40300 \\
\mathrm{~kg} \text { per month for different crop at } 120 \mathrm{~kg} \text { and } \\
960 \mathrm{~kg} \text {. }\end{array}$ \\
\hline
\end{tabular}

Energy-economic-environmental analysis of solar drying system: a review (Wan Nurlaila Yusra Mat Desa) 
Embodied energy (EE) is the total energy required to produce any items, things, or services [40]. It is a variable commonly used in environmental analysis, to determine how much energy is associated with producing a unit of system by taking into account the energy used in extraction, processing, manufacturing, and transporting of the materials [52]. The calculations on EE serve as an indicator of the overall environmental impacts of materials and systems, as the energy consumed correlates to $\mathrm{CO}_{2}$ production which contributes to GHG emission. In analysis, EE calculation requires the quantification of the materials used in the construction and maintenance of the dryer over its entire life time. The mass values of the different materials were then multiplied by the embodied energy coefficients of the corresponding materials (EEC), usually expressed in $\mathrm{MJ} \mathrm{kg}^{-1}$ to give the total $\mathrm{EE}$ for the overall equipment [53].

Energy Payback Time (EPBT) is the time required to pay back the EE, can be calculated as

$$
E P B T=\frac{\text { Embodied Energy }}{\text { Annual Energy Output }}
$$

Carbon credit is a tool that represents any tradable certificate or permit that grants the right for businesses or industries to emit one tone of carbon or carbon dioxide equivalent, which is essential in the application of emission trading approach [54]. They provide a way to reduce greenhouse effect emissions on an industrial scale by capping total annual emissions and letting the market assign a monetary [51]. Carbon credit model is commonly used to calculate the carbon mitigation involved with the usage of solar dryers, as well as the earned carbon credit associated. The overall $\mathrm{CO}_{2}$ mitigation over dryer lifetime is calculated as the difference of total $\mathrm{CO}_{2}$ mitigation and total $\mathrm{CO}_{2}$ emission

$$
\begin{aligned}
& \text { Net mitigation of } \mathrm{CO} 2 \text { over lifetime }=\text { Total CO2 mitigation }- \text { Total CO2 emission } \\
& \qquad=\left[E_{a} \times n \times X-E E\right] \mathrm{kg}
\end{aligned}
$$

where $E_{a}$ is the annual thermal output energy of the dryer, $n$ is the dryer lifetime, and $X$ is the $\mathrm{CO}_{2}$ mitigation per $\mathrm{kWh}$ of the dryer. The equation for $\mathrm{X}$ is given as follows

$$
X=\frac{1}{1-L_{a}} \times \frac{1}{1-L_{t d}} \times 0.98
$$

where the first term accounts for power consumption loss, $L_{a}(10 \%)$, and second term for energy loss due to transmission and distribution, $L_{t d}(45 \%)$. Therefore, at given $L_{a}$ and $L_{t d}$ values, the amount of $\mathrm{CO}_{2}$ mitigation of the system, $\mathrm{X}$ is determined to be $2.01 \mathrm{~kg}$.

From the quantified net lifetime $\mathrm{CO}_{2}$ mitigation of the dryer system, earned carbon credit can be calculated by multiplying the value with the cost of carbon credit, D which ranges from USD 5-20 per ton of $\mathrm{CO}_{2}$.

$$
\text { Carbon credit }=\text { Net mitigation of CO2 over lifetime } \times D
$$

A simpler environmental analysis was performed by Elhage et al. who studied the amount of $\mathrm{CO}_{2}$ reduction in relation to percentage of solar dryer usage, mass of drying sample and type of food being dried under Lebanese climate. By quantifying the amount of energy consumption per month of the dryer $E_{\text {month }}$, the amount of $\mathrm{CO}_{2}$ produced $M_{\text {produced,CO2 }}$ and amount of reduction in $\mathrm{CO}_{2}$ emission $M_{\text {reduced,CO2 }}$ by the system is quantified as

$$
\begin{aligned}
& M_{\text {produced, } \mathrm{CO} 2}=E_{\text {month }} \times M_{\frac{\mathrm{CO} 2}{k W h}} \\
& M_{\text {reduced, } \mathrm{CO} 2}=\operatorname{Pr} \times M_{\text {produced }, \mathrm{CO} 2}
\end{aligned}
$$

where $M_{\frac{\mathrm{CO} 2}{k W h}}$ is the amount of $\mathrm{CO}_{2}$ produced from $1 \mathrm{kWh}$ electricity which differs from one place to another.

\section{CONCLUSIONS}

Solar drying is a highly potential application of solar thermal technology. The use of solar dryers for drying of agricultural produce as well as poultry and marine products results in higher product quality through better control of drying process. One approach to evaluate the thermal performance of solar dryers is done through energy analysis which is discussed in detail in this review. Solar dryers also contribute to environmental conservation, as it reduces the energy demand in the food post-harvesting sector. To evaluate

Int J Pow Elec \& Dri Syst, Vol. 11, No. 2, June 2020 : 1011 - 1018 
the financial savings and environmental impact, economic and environmental analysis suitable for solar dryer systems were outlined in this review.

\section{ACKNOWLEDGEMENTS}

The authors would like to thank the UKM for funding UKM-Simedarby (KK-2014-014).

\section{REFERENCES}

[1] A. Tiwari, "A Review on Solar Drying of Agricultural Produce," J. Food Process. Technol., vol. 7, no. 9, 2016.

[2] A. Fudholi, M.H. Ruslan, M.Y. Othman, M.Yahya, A. Zaharim, K. Sopian. "Collector efficiency of the double-pass solar air collectors with fins. Proceedings of the 9th WSEAS International Conference on SYSTEM SCIENCE and SIMULATION in ENGINEERING (ICOSSSE'10), Japan, 2010, October 4-6, pp. 428-34, 2010.

[3] A. Fudholi, K. Sopian," Review on exergy and energy analysis of solar air heater," International Journal of Power Electronics and Drive Systems (IJPEDS), vol. 9, no. 1, pp. 420-426, 2018.

[4] A. Fudholi, K. Sopian," Review on solar collector for agricultural produce, "International Journal of Power Electronics and Drive Systems (IJPEDS), vol. 9, no. 1, pp. 414-419, 2018.

[5] M. Zohri, N. Nurato, A. Fudholi," Photovoltaic-thermal (PVT) system with and without fins collector: theoretical approach, " International Journal of Power Electronics and Drive Systems (IJPEDS), vol. 8, no. 4, pp. 1756-1763, 2017.

[6] M. Zohri, N. Nurato, L.D. Bakti, A. Fudholi, "Exergy assessment of photovoltaic thermal with V-groove collector; theoretical study," TELKOMNIKA (Telecommunication Computing Electronics and Control), vol. 16, no. 2, pp. 55057, 2018.

[7] N.S. Nazri, A. Fudholi, M.H. Ruslan, K. Sopian, "Mathematical modeling of photovoltaic thermal-thermoelectric (PVT-TE) air collector," International Journal of Power Electronics and Drive Systems (IJPEDS), vol. 9, no. 2, pp. 795-802, 2018

[8] N.F.M. Razali, A. Fudholi, M.H. Ruslan, K. Sopian," Review of water-nanofluid based photovoltaic/thermal (PV/T) systems," International Journal of Electrical and Computer Engineering (IJECE), vol 9, no. 1, pp. 134-140, 2019.

[9] A. Fudholi, M.F. Musthafa, K. Sopian," Review of solar photovoltaic/thermal (PV/T) air collector," International Journal of Electrical and Computer Engineering (IJECE), vol. 9, no. 1, pp. 126-133, 2019.

[10] N.F.M. Razali, A. Fudholi, M.H. Ruslan, K. Sopian," Experiment study of water based photovoltaic-thermal (PV/T) collector," International Journal of Electrical and Computer Engineering (IJECE), vol. 9, no. 1, pp. 118-125, 2019.

[11] A. Fudholi, M.F. Musthafa, K. Sopian, "Energy and exergy analysis of air based photovoltaic thermal (PVT) collector: a review," International Journal of Electrical and Computer Engineering (IJECE), vol. 9, no. 1, pp. 109$117,2019$.

[12] N.F.M. Razali, A. Fudholi, M.H. Ruslan, K. Sopian, "Electrical characteristic of photovoltaic thermal collector with water-multiwalled carbon nanotube nanofluid flow," Indonesian Journal of Electrical Engineering and Computer Science, vol. 13, no. 1, pp. 324-330, 2019.

[13] N.S. Nazri, A. Fudholi, M.H. Ruslan, K. Sopian, "Experimental study of photovoltaic thermal-thermoelectric (PVTTE) air collector," International Journal of Power Electronics and Drive Systems (IJPEDS), vol. 9, no. 3, pp. 1406$1412,2018$.

[14] A. Fudholi, K. Sopian, "R\&D of photovoltaic thermal (PVT) systems: an overview," International Journal of Power Electronics and Drive Systems (IJPEDS), vol. 9, no. 2, pp. 803-10, 2018.

[15] M. Mustapha, A. Fudholi, C.H. Yen, M.H. Ruslan, K. Sopian, "Review on energy and exergy analysis of air and water based photovoltaic thermal (PVT) collector," International Journal of Power Electronics and Drive Systems (IJPEDS), vol. 9, no. 3, pp. 1383-1389, 2018

[16] A. Ibrahim, S. Mat, A.F. Abdullah, A. Fudholi, K. Sopian, (2018), "Outdoor performance evaluation of building integrated photovoltaic thermal (BIPVT) solar collector with spiral flow absorber configurations, " International Journal of Power Electronics and Drive Systems (IJPEDS), vol. 9, no. 4, pp. 1918-1925, 2018.

[17] A. Fudholi, M.K.B.M. Ali, M. Mohammad, M.Y. Othman, M.H. Ruslan, K. Sopian, "Solar drying technology: an overview," International Journal of Power Electronics and Drive Systems (IJPEDS), vol. 9, no. 4, pp. 1804-1813, 2018.

[18] A. Fudholi, K. Sopian, M. Gabbasa, B. Bakhtyar, M. Yahya, M.H. Ruslan, S. Mat, "Techno-economic of solar drying systems with water based solar collectors in Malaysia: a review. "Renew. Sustain. Energy Rev., vol. 51, pp. 809-820, 2015.

[19] M. Yahya, A. Fudholi, H. Hafizh, K. Sopian, "Comparison of solar dryer and solar-assisted heat pump dryer for cassava,". Sol. Energy, vol. 136, pp. 606-613, 2016.

[20] A. Fudholi, K. Sopian, B. Bakhtyar, M. Gabbasa, M.Y. Othman, M.H. Ruslan, "Review of solar drying systems with air based solar collectors in Malaysia,"Renew. Sustain. Energy Rev., vol. 51, pp. 1191-1204, 2015.

[21] M. Yahya, A. Fudholi, K. Sopian, "Performance and economic analyses on solar-assisted heat pump fluidised bed dryer integrated with biomass furnace for rice drying," Sol. Energy, vol. 174, pp. 1058-1067, 2018.

[22] K. Hansen and B. Vad Mathiesen, "Comprehensive assessment of the role and potential for solar thermal in future energy systems," Sol. Energy, vol. 169, no. March, pp. 144-152, 2018.

[23] A. Kylili, P. A. Fokaides, A. Ioannides, and S. Kalogirou, "Environmental assessment of solar thermal systems for the industrial sector," J. Clean. Prod., vol. 176, pp. 99-109, 2018.

Energy-economic-environmental analysis of solar drying system: a review (Wan Nurlaila Yusra Mat Desa) 
[24] A. Sreekumar and K. Rajarajeswari, “Accelerated food processing through solar drying system," in International Conference on Mechanical, Materials and Renewable Energy, 2018.

[25] P. Singh, V. Shrivastava, and A. Kumar, "Recent developments in greenhouse solar drying: A review," Renew. Sustain. Energy Rev., vol. 82, no. September, pp. 3250-3262, 2018.

[26] A. Fudholi, K. Sopian, M. H. Ruslan, M. A. Alghoul, and M. Y. Sulaiman, "Review of solar dryers for agricultural and marine products," Renew. Sustain. Energy Rev., vol. 14, no. 1, pp. 1-30, 2010.

[27] A. Sharma, C. R. Chen, and N. Vu Lan, "Solar-energy drying systems: A review," Renew. Sustain. Energy Rev., vol. 13, no. 6-7, pp. 1185-1210, 2009.

[28] A. Fudholi, R. Yendra, D. F. Basri, M. H. Ruslan, and Kamaruzzaman Sopian, "Energy and exergy analysis of hybrid solar drying system," Contemp. Eng. Sci., vol. 9, no. 5, pp. 215-223, 2011.

[29] T. Boroze, H. Desmorieux, J. M. Méot, C. Marouzé, Y. Azouma, and K. Napo, "Inventory and comparative characteristics of dryers used in the sub-Saharan zone: Criteria influencing dryer choice," Renew. Sustain. Energy Rev., vol. 40, pp. 1240-1259, 2014.

[30] S. K. Sansaniwal, V. Sharma, and J. Mathur, "Energy and exergy analyses of various typical solar energy applications : A comprehensive review," Renew. Sustain. Energy Rev., no. July, pp. 0-1, 2017.

[31] T. K. Chand, M. K. Mohanty, and R. C. Mohanty, "An Overview of Solar Energy and its Application in Solar Dryers with Brief Concept of Energy and Energy Analysis," Int. J. Res., vol. 2, no. 1, pp. 870-877, 2015.

[32] R. Kumar, "A critical review on energy, exergy, exergoeconomic and economic (4-E) analysis of thermal power plants," Eng. Sci. Technol. an Int. J., vol. 20, no. 1, pp. 283-292, 2017.

[33] B. O. Bolaji, "Exergetic Analysis of Solar Energy drying Systems," Nat. Resour., vol. 02, no. 02, pp. 92-97, 2011.

[34] Y. Baradey, M. N. A. Hawlader, A. F. Ismail, M. Hrairi, and M. I. Rapi, "Solar drying of fruits and vegetables," vol. 5, no. 1, pp. 2-6, 2016

[35] M. Yahya, A. Fudholi, and K. Sopian, "Energy and exergy analyses of solar-assisted fluidized bed drying integrated with biomass furnace," Renew. Energy, vol. 105, pp. 22-29, 2017.

[36] A. Fudholi, M.Y. Othman, M.H. Ruslan, S. Mat, "Prospect and Future of Solar Dryer for Agricultural and Marine Product : Perspective Malaysia," Latest Trends Renew. Energy Environ. Informatics Prospect, pp. 141-149.

[37] M. Kumar, S. K. Sansaniwal, and P. Khatak, "Progress in solar dryers for drying various commodities," Renew. Sustain. Energy Rev., vol. 55, pp. 346-360, 2016.

[38] A. Lingayat, V. P. Chandramohan, and V. R. K. Raju, "Design, Development and Performance of Indirect Type Solar Dryer for Banana Drying," in Energy Procedia, vol. 109, 2017.

[39] S. Abubakar, S. Umaru, M. U. Kaisan, U. A. Umar, B. Ashok, and K. Nanthagopal, "Development and performance comparison of mixed-mode solar crop dryers with and without thermal storage," Renew. Energy, vol. 128, pp. 285 298, 2018.

[40] O. Prakash, A. Kumar, and V. Laguri, "Performance of modified greenhouse dryer with thermal energy storage," Energy Reports, vol. 2, pp. 155-162, 2016.

[41] T. Phahom, S. Phoungchandang, and W. L. Kerr, "Effects of steam-microwave blanching and different drying processes on drying characteristics and quality attributes of Thunbergia laurifolia Linn. leaves," J. Sci. Food Agric., vol. 97, no. 10, pp. 3211-3219, 2017.

[42] D. I. Onwude, N. Hashim, R. B. Janius, N. M. Nawi, and K. Abdan, "Modeling the Thin-Layer Drying of Fruits and Vegetables: A Review," Compr. Rev. Food Sci. Food Saf., vol. 15, no. 3, pp. 599-618, 2016.

[43] A. Abusoglu and M. Kanoglu, "Exergoeconomic analysis and optimization of combined heat and power production: A review," Renew. Sustain. Energy Rev., vol. 13, no. 9, pp. 2295-2308, 2009.

[44] A. A. Mathew and T. Venugopal, "Solar power drying system: a comprehensive assessment on types, trends, performance and economic evaluation," Int. J. Ambient Energy, pp. 1-24, 2018.

[45] A. ELkhadraoui, S. Kooli, I. Hamdi, and A. Farhat, "Experimental investigation and economic evaluation of a new mixed-mode solar greenhouse dryer for drying of red pepper and grape," Renew. Energy, vol. 77, pp. 1-8, 2015.

[46] O. Prakash and A. Kumar, "Environomical analysis and mathematical modelling for tomato flakes drying in a modified greenhouse dryer under active mode," Int. J. Food Eng., vol. 10, no. 4, pp. 669-681, 2014.

[47] H. El Hage, A. Herez, M. Ramadan, H. Bazzi, and M. Khaled, "An investigation on solar drying: A review with economic and environmental assessment," Energy, vol. 157, pp. 815-829, 2018.

[48] P. Purohit and T. C. Kandpal, "Solar crop dryer for saving commercial fuels: A techno-economic evaluation," Int. J. Ambient Energy, vol. 26, no. 1, pp. 3-12, 2005.

[49] M. Keke, M. Abdulbashir, F. Salako, S. Kayode, A. Ifeoluwa, and A. Adefila, "Qualitative performance and economic analysis of low cost solar fish driers in Sub-Saharan Africa," vol. 2, no. 1, pp. 64-69, 2014.

[50] M. Liu, S. Wang, and K. Li, "Study of the Solar Energy Drying Device and Its Application in Traditional Chinese Medicine in Drying," Int. J. Clin. Med., no. April, pp. 271-280, 2015.

[51] S. Nayak, A. Kumar, J. Mishra, and G. N. Tiwari, "Drying and testing of mint (Mentha piperita) by a hybrid photovoltaic-thermal (PVT)-based greenhouse dryer," Dry. Technol., vol. 29, no. 9, pp. 1002-1009, 2011.

[52] V. Shrivastava and A. Kumar, "Embodied energy analysis of the indirect solar drying unit," Int. J. Ambient Energy, vol. 38, no. 3, pp. 280-285, 2017.

[53] M. Hasan and T. A. G. Langrish, "Development of a sustainable methodology for life-cycle performance evaluation of solar dryers," Sol. Energy, vol. 135, pp. 1-13, 2016.

[54] M. Luxmore, C. Tauyanashe, and M. Lawrence, "Carbon Financing for Renewable Energy Projects in Zimbabwe A Case of Chipendeke Micro-Hydro Scheme,” Int. J. Sci. Res., vol. 2, no. 9, pp. 370-374, 2013.

Int J Pow Elec \& Dri Syst, Vol. 11, No. 2, June 2020 : 1011 - 1018 